\title{
The impact of DNA parentage verification on breeding value estimation and sire ranking in South African Angora goats
}

\author{
C. Garritsen ${ }^{1}$, E. Van Marle-Köster ${ }^{1}$, M.A. Snyman ${ }^{2}$ and C. Visser $^{1}$ \\ ${ }^{1}$ Department of Animal and Wildlife Sciences, University of Pretoria, Pretoria, 0002, South Africa \\ ${ }^{2}$ Grootfontein Agricultural Development Institute, Private Bag X529, Middelburg (EC), 5900, South Africa
}

\begin{abstract}
Pedigree integrity plays a crucial role in the achievement of genetic progress in livestock selection programmes. DNA marker-based parentage testing has become a useful tool for amending inaccuracies in on-farm pedigree records. In the current study, the extent of inaccurate and incomplete pedigree records was quantified in 381 South African Angora goats using a 12 microsatellite markers. Eight half-sib families with a total of 317 Angora kids, 40 kids with unknown sires and an additional 16 putative sires were included in the study. $14.3 \%$ of the on-farm pedigrees were amended, including incorrect (according to the DNA verification) or incomplete records. Estimated breeding values (EBV) for fleece traits (fibre diameter and fleece weight) as well as body weights (birth weight and weaning weight) were calculated for 21 sires using ASREML, firstly for the breeder's recorded pedigree and secondly for the DNA-verified pedigree. An overall greater effect was observed in body weight traits than in fleece weight traits with regard to sire EBVs and the ranking thereof. The significant change realised in sire ranking after DNA marker-based pedigree verification emphasises the importance of pedigree integrity in maximising selection accuracy for the production of the highest quality mohair clip in the South African Angora goat industry.
\end{abstract}

Keywords: Body weight, fleece traits, microsatellite markers, pedigree integrity, sire selection \#Corresponding author: carina.visser@up.ac.za 


\section{Introduction}

South Africa is the largest mohair-producing country in the world, contributing around $50 \%$ to global production annually (Mohair South Africa, 2012; DAFF, 2013). Selection of Angora goats is largely based on phenotypic recording with fleece weight (FW), fibre diameter (FD) and body weights being the most important traits. Mohair selection traits include both physical and quality traits with fibre diameter (FD) being the most important economically, determining both the price and the processing of the fibre. General consensus is that fibre diameter and fleece weight should both be selected on by making use of a selection index (Snyman et al. 1996; Snyman, 2002). Body weight is included in the selection index used by Angora goat farmers, both because of its importance in reproduction and adaptability and to counteract the unfavourable correlated response when selecting for decreased fibre diameter. Selection for increased body weight should have an additional benefit of higher mature weight and improved reproduction rates of young does and survivability of kids (Snyman, 2007, 2011a, 2011b, 2012; Goosen et al., 2010). EBVs are also applied in selection programmes and are based on the assumption that pedigrees are accurate and complete. Accurate pedigrees are important for effective selection decisions that will ensure genetic progress required for South African Angora goat breeders to maintain a competitive position in the world market.

South African Angora goats are farmed under extensive conditions. Numbers in the doe herds of stud breeders range from 250 to 700 , while those in commercial herds could reach up to 4000 does. Stud breeders make use of individual mating, either via artificial insemination or single-sire mating, where each sire is run with its allocated group of does. This is followed by over-mating in the form of group mating, where all the rams are put together with all the does for an additional oestrus cycle. This mating practice limits accurate pedigree recording. Commercial breeders in South Africa make use of group mating by putting all the male and female animals together, rendering pedigree recording impossible. Pedigree recording thus only takes place in stud herds, experimental herds and in certain group breeding schemes.

Improved response to selection of up to $29 \%$ has been realised when using EBVs compared to using the animals' own performance in a selection index (Sorensen, 1987), due to the inclusion of pedigree information in the estimation of EBVs (Belonsky and Kennedy, 1988). Studies have shown that errors in pedigree records have a negative effect on genetic gain by introducing bias in the estimation of genetic 
parameters, specifically the under-estimation of heritability of quantitative traits (Visscher et al. 2002; Pollak, 2005). Misidentified parentage also results in inaccurate EBV estimations, resulting in slow genetic progress. The study of Visscher et al. (2002) reported an estimated decrease of 2-3\% in response to selection in the presence of $10 \%$ pedigree errors in dairy cattle, while Banos et al. (2001) estimated a decrease of 11 to $15 \%$ in genetic improvement, due to errors in pedigree records in dairy cattle. Angora goat breeders make use of sire ranking based on either EBVs or performance records as a method of selecting the most superior sires in the herd. EBVs estimated using erroneous pedigrees are unreliable (since EBVs are estimated using a relationship matrix) and therefore may have a severe effect on sire ranking, as reported in cattle by Van Eenennaam et al. (2007).

Microsatellite markers have been used extensively for relationship testing in various livestock species (Putnova et al. 2003; Van Eenennaam et al. 2007; Avdi and Banos, 2008; Bolormaa et al. 2008; Rendo et al. 2011). These DNA markers are especially suited to parentage studies because of their high level of polymorphism and their abundance in the eukaryotic genome (Queller et al. 1993; Webster and Reichart, 2005). A panel of microsatellite markers specifically suited for parentage verification in South African Angora goats was designed by Friedrich (2009) and was applied in the current study.

The aim of the study was to determine the effect that pedigree inaccuracies have on EBV estimation and sire ranking for traits of economic importance (including fleece weight, fibre diameter and body weight) in South African Angora goats.

\section{Materials and Methods}

Resources from one stud breeder were used for this study. Blood samples, pedigrees and phenotypic data were obtained from the South African Small Stock Biobank at the Grootfontein Agricultural Development Institute (GADI) in Middelburg, Eastern Cape, South Africa, with ethical approval from the Ethics Committee of the Faculty of Natural and Agricultural Sciences at the University of Pretoria (EC1110018-073).

The animals used for DNA parentage verification comprised 381 Angora goats of the above mentioned stud breeder, consisting of 317 Angora goat kids and eight sires in eight half-sib families, 40 
(unallocated) Angora kids with no on-farm recorded paternity and 16 putative sires. Individuals were selected based on availability of blood and phenotypic data, completeness of pedigree and half-sib family size.

The breeder makes use of artificial insemination (AI), single-sire mating and group mating. AI is performed during the first 3 to 5 days of the mating season (usually early March). All does that are selected for AI are synchronised. Single-sire mating starts at roughly the same time (beginning to mid-March), where a herd of does are placed in a camp together with one sire. These does are left with the sires for two mating cycles (roughly 42 days). The mating season is then concluded with a cycle of group mating (roughly 21 days), where all the does and sires are placed together in one camp. The group mating follows directly on the single-sire mating, with no time-lapse in between. Young does entering the breeding herd for the first time are not subjected to AI or single-sire mating, but are group mated from the middle of March until the end of the mating season. They are placed into a camp with their group of sires (known as "putative" sires in the current study).

Consequently, kids that are born early in the lambing season (from August until early September) may have been conceived through AI or single-sire mating in the case of older does, or group mating in the case of young does. Kids born from the third week of September onwards are most likely to have been conceived during the third cycle group mating period. Those that are born around the middle of September could have been conceived either way.

DNA extraction was performed using the Qiagen DNeasy Blood and Tissue kit ${ }^{\circledR}$ (Qiagen - Whitehead Scientific [Pty] Ltd, Cape Town, South Africa) according to the manufacturer's instructions at the Department of Animal and Wildlife Sciences, Faculty of Natural and Agricultural Sciences, University of Pretoria, South Africa. The microsatellite panel used in the current study was developed in a previous study by Friedrich (2009) specifically for parentage testing in the South African population of Angora goats. During marker optimisation two markers (SRCRSP9 and SRCRSP24) were discarded from the panel as they failed to amplify. The final panel consisted of markers BM1258, OarFCB48, INRA63, BM1818, CSRD247, MCM527, INRABERN 192, BM7160, SRCRSP8, BM1329, HSC and SRCRSP5. PCR reactions consisted of a final volume of $15 \mu \mathrm{L} .10 \mu \mathrm{L}$ contained the master mix and primer-Taq mix in the following 
composition: $6.1 \mu \mathrm{L}$ molecular grade distilled water and $3 \mu \mathrm{L}$ Bioline MyTaq ${ }^{\circledR}$ 5x reaction buffer (containing buffer, $\mathrm{MgCl}_{2}$ and dNTPs - Celtic Diagnostics Inc, South Africa), $0.3 \mu \mathrm{L}$ Bioline MyTaq ${ }^{\circledR}$ polymerase enzyme and $0.3 \mu \mathrm{L}$ of the forward and reverse primer for each marker (concentration of $10 \mathrm{pmol} / \mu \mathrm{L}$ ). $5 \mu \mathrm{L}$ DNA, with a concentration of between $60 \mathrm{ng} / \mu \mathrm{L}$ and $120 \mathrm{ng} / \mu \mathrm{L}$, was then added to the mixture to make up the total volume of $15 \mu \mathrm{L}$. PCR amplifications were performed using a GeneAmp ${ }^{\circledR}$ PCR System 9700 thermocycler (Applied Biosystems, Foster City, USA) and a Kyratech Supercycler ${ }^{\circledR}$ (Celtic Diagnostics Inc Cape Town, South Africa). The PCR programme included a denaturation step of 10 minutes at $94^{\circ} \mathrm{C}, 33$ cycles of 45 seconds at $94^{\circ} \mathrm{C}, 80$ seconds at the marker's annealing temperature (indicated in Table 1) and 60 seconds at $72^{\circ} \mathrm{C}$, and a final extension step of five minutes at $72^{\circ} \mathrm{C}$. PCR products were diluted in the ratio of 1:10 with distilled water for genotyping on an Applied Biosystems 3500xL Genetic Analyser (Life Technologies, Carlsblad, US) at the Forestry and Agriculture Biotechnology Institute (FABI) at the University of Pretoria. Alleles were called using GeneMarker ${ }^{\circledR}$ software (SoftGenetics ${ }^{\circledR}$, LLC, CA, USA).

Allele frequencies, polymorphic information content (PIC) and expected and observed heterozygosity $\left(\mathrm{H}_{\mathrm{E}}\right.$ and $\left.\mathrm{H}_{\mathrm{O}}\right)$ were computed using Microsoft Excel-based MS Toolkit ${ }^{\circledR}$ software (Park, 2001). The parentage analysis was performed using Cervus ${ }^{\circledR} 3.0$ (Marshall et al. 1998). LOD and Delta scores for each parentage assignment as well as CPE of the marker panel were computed using Cervus ${ }^{\circledR} 3.0$ (Marshall et al. 1998). The interpretation of LOD scores was carried out according the method of Slate et al. (2000).

The data set used for the estimation of sire breeding values comprised 5077 records of Angora goat kids born from 2000 until 2009 in the relevant stud. EBVs for each sire were computed using the ASREML programme (Gilmour et al. 2002) for traits of economic importance. Traits included in the analysis include birth weight, weaning weight (four-month weight), 8-month weight, 12-month weight, 16-month weight and two fleece traits, namely second shearing fleece weight and average fibre diameter.

The data was initially analysed by least-squares methods to identify the non-genetic effects which contributed significantly to variation, using the General Linear Model (GLM) procedure of the SAS computer package (SAS, 2009). Variance components were estimated using the ASREML programme of Gilmour et al. (2002). Single-trait animal models were fitted for all traits. Direct additive and maternal additive genetic effects, with or without a covariance between them, and maternal permanent environmental 
effects were used in different combinations to yield six models, which were fitted for all traits to determine the most suitable model for estimation of breeding values.

The six models were:

$$
\begin{aligned}
& y=X b+Z_{1} a+e \\
& y=X b+Z_{1} a+Z_{2} c+e \\
& y=X b+Z_{1} a+Z_{2} m+e ; \text { with } \operatorname{cov}(a, m)=0 \\
& y=X b+Z_{1} a+Z_{2} m+e ; \text { with } \operatorname{cov}(a, m)=A \sigma_{a m} \\
& y=X b+Z_{1} a+Z_{2} m+Z_{3} c+e ; \text { with } \operatorname{cov}(a, m)=0 \\
& y=X b+Z_{1} a+Z_{2} m+Z_{3} c+e ; \text { with } \operatorname{cov}(a, m)=A \sigma_{a m}
\end{aligned}
$$

where $\mathrm{y}$ is a vector of observed traits of animals.

b, a, $\mathrm{m}$ and $\mathrm{c}$ are vectors of fixed effects, direct additive genetic effects, maternal additive genetic effects and maternal permanent environmental effects respectively.

$\mathrm{X}, \mathrm{Z}_{1}, \mathrm{Z}_{2}$ and $\mathrm{Z}_{3}$ are incidence matrices respectively relating fixed effects, direct additive genetic effects, maternal additive genetic effects and maternal permanent environmental effects to $y$. $\mathrm{e}$ is the vector of residuals; $\mathrm{A}$ is a numerator relationship matrix.

$\sigma_{\mathrm{am}}$ is the covariance between direct additive genetic and maternal additive genetic effects.

Log likelihood ratio tests were carried out amongst all six models to determine the most appropriate model for each trait (Morrell, 1998). Model 5 was the most appropriate for birth weight, weaning weight, eight month weight and 12-month weight. Model 1 was the most appropriate for 16-month weight, fleece weight and fibre diameter.

Estimated breeding values and accuracies were obtained as back solutions with the ASREML programme (Gilmour et al. 2002). EBVs were estimated twice. Firstly with the pedigree records as obtained from the breeder, and secondly with pedigrees according to DNA-based parentage verification after correct offspring have been assigned and previously unknown offspring allocated to correct sires. 
Accuracies of EBVs were calculated as

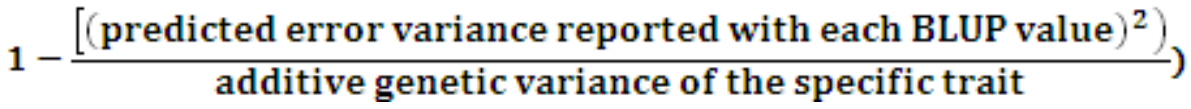

Breeding sires were ranked according to breeding values for each trait evaluated. Sires were initially ranked according to the EBVs estimated using the breeder's pedigree records and then again after restructuring of pedigrees according to DNA-based parentage allocation and revised estimation of sire EBVs. Ranking was done using the Spearman rank correlation method of Long et al. (1990).

\section{Results}

The microsatellite marker panel was evaluated in terms of observed and expected heterozygosities $\left(\mathrm{H}_{\mathrm{O}}\right.$ and $\left.\mathrm{H}_{\mathrm{E}}\right)$, Polymorphic Information Content (PIC), null allele frequency and Probability of exclusion for sire alone $(\mathrm{PE})$ as presented in Table 1.

Table 1 Observed and expected heterozygosities, PIC values, $\mathrm{F}_{\text {Null }}$ and PE values for 12 microsatellite markers used in the current study

\begin{tabular}{|c|c|c|c|c|c|}
\hline Locus $\left(\mathrm{T}_{\mathrm{A}}\right)$ & $\mathrm{H}_{\mathrm{O}}$ & $\mathrm{H}_{\mathrm{E}}$ & PIC & $\mathrm{F}_{\text {Null }}$ & $\mathrm{PE}$ \\
\hline INRA63 $\left(54^{\circ} \mathrm{C}\right)$ & 0.696 & 0.772 & 0.738 & +0.046 & 0.615 \\
\hline $\mathrm{BM} 1818\left(58^{\circ} \mathrm{C}\right)$ & 0.802 & 0.786 & 0.752 & -0.010 & 0.596 \\
\hline $\mathrm{CSRD} 247\left(55^{\circ} \mathrm{C}\right)$ & 0.731 & 0.691 & 0.642 & -0.028 & 0.721 \\
\hline $\operatorname{MCM} 527\left(55^{\circ} \mathrm{C}\right)$ & 0.696 & 0.760 & 0.723 & +0.037 & 0.627 \\
\hline $\mathrm{BM} 1258\left(58^{\circ} \mathrm{C}\right)$ & 0.761 & 0.789 & 0.762 & +0.016 & 0.572 \\
\hline OarFCB48 $\left(60^{\circ} \mathrm{C}\right)$ & 0.822 & 0.761 & 0.725 & -0.047 & 0.626 \\
\hline $\mathrm{BM} 7160\left(55^{\circ} \mathrm{C}\right)$ & 0.580 & 0.631 & 0.557 & +0.041 & 0.788 \\
\hline SRCRSP8 $\left(55^{\circ} \mathrm{C}\right)$ & 0.751 & 0.720 & 0.679 & -0.021 & 0.679 \\
\hline $\mathrm{BM} 1329\left(55^{\circ} \mathrm{C}\right)$ & 0.732 & 0.709 & 0.660 & -0.022 & 0.702 \\
\hline $\operatorname{HSC}\left(55^{\circ} \mathrm{C}\right)$ & 0.871 & 0.842 & 0.823 & -0.019 & 0.477 \\
\hline SRCRSP5 $\left(55^{\circ} \mathrm{C}\right)$ & 0.796 & 0.770 & 0.741 & -0.019 & 0.605 \\
\hline INRABERN192 $\left(54^{\circ} \mathrm{C}\right)$ & 0.699 & 0.629 & 0.602 & -0.069 & 0.758 \\
\hline Average & 0.745 & 0.738 & 0.700 & - & 0.647 \\
\hline
\end{tabular}

$\mathrm{T}_{\mathrm{A}}$ : Annealing temperature

$\mathrm{H}_{\mathrm{O}}$ : Observed heterozygosity

$\mathrm{H}_{\mathrm{E}}$ : Expected heterozygosity

PIC: Polymorphic Information content

$\mathrm{F}_{\text {Null }}$ : Null allele frequency

PE: Probability of exclusion for sire alone 
Observed heterozygosity $\left(\mathrm{H}_{\mathrm{O}}\right.$ ) ranged from 0.579 (BM7160) to 0.871 (HSC), with a mean of 0.745 as per Table 1. Expected heterozygosity $\left(\mathrm{H}_{\mathrm{E}}\right)$ ranged from 0.629 (INRABERN192) to 0.842 (HSC), with a

Table 2 Parentage allocation of Family D with 12 microsatellite markers

\begin{tabular}{|c|c|c|c|c|c|c|}
\hline Offspring ID & Allocated sire ID & Recorded sire ID & Pair loci compared & Pair loci mismatched & LOD score & Confidence $^{\mathrm{d}}$ \\
\hline $142 / 08208$ & D1 & D1 & 12 & 0 & 4.990 & $*$ \\
\hline $142 / 08237$ & D1 & D1 & 12 & 0 & 4.430 & $*$ \\
\hline $142 / 08241$ & D1 & D1 & 10 & 0 & 3.930 & $*$ \\
\hline $142 / 08242$ & D1 & D1 & 12 & 0 & 7.420 & $*$ \\
\hline $142 / 08243$ & D1 & D1 & 12 & 0 & 8.970 & $*$ \\
\hline $142 / 08244$ & D1 & D1 & 11 & 0 & 6.060 & $*$ \\
\hline $142 / 08253$ & D1 & D1 & 12 & 0 & 5.400 & $*$ \\
\hline $142 / 08262$ & D1 & D1 & 12 & 0 & 3.920 & $*$ \\
\hline $142 / 08271$ & D1 & D1 & 12 & 0 & 6.070 & $*$ \\
\hline $142 / 08283$ & D1 & D1 & 12 & 1 & 0.590 & $*$ \\
\hline $142 / 08298$ & D1 & D1 & 12 & 0 & 5.840 & $*$ \\
\hline $142 / 08316$ & D1 & D1 & 12 & 0 & 5.980 & $*$ \\
\hline $142 / 08317$ & D1 & D1 & 12 & 0 & 6.960 & $*$ \\
\hline $142 / 08318$ & D1 & D1 & 12 & 0 & 6.580 & $*$ \\
\hline $142 / 08339$ & D1 & D1 & 12 & 0 & 1.800 & $*$ \\
\hline $142 / 08356$ & D1 & D1 & 12 & 0 & 4.680 & $*$ \\
\hline $142 / 08360$ & D1 & D1 & 12 & 1 & 3.410 & $*$ \\
\hline $215 / 08706$ & D1 & D1 & 10 & 0 & 5.230 & $*$ \\
\hline $215 / 08707$ & D1 & D1 & 12 & 0 & 2.530 & $*$ \\
\hline $215 / 08708$ & D1 & D1 & 12 & 1 & 1.720 & $*$ \\
\hline $215 / 08742$ & D1 & D1 & 10 & 0 & 6.630 & $*$ \\
\hline $215 / 08774$ & D1 & D1 & 12 & 0 & 6.430 & $*$ \\
\hline $215 / 08775$ & D1 & D1 & 12 & 1 & 4.090 & $*$ \\
\hline 215/08789 & D1 & D1 & 11 & 0 & 4.970 & $*$ \\
\hline $215 / 08792$ & D1 & D1 & 12 & 0 & 4.480 & $*$ \\
\hline $317 / 08049$ & D1 & D1 & 8 & 0 & 2.580 & $*$ \\
\hline $317 / 08081$ & D1 & D1 & 12 & 2 & -3.880 & $*$ \\
\hline $317 / 08082$ & D1 & D1 & 12 & 0 & 6.190 & $*$ \\
\hline $154 / 06605^{\mathrm{ac}}$ & D1 & D1 & 12 & 2 & -6.380 & $*$ \\
\hline $142 / 06298^{\mathrm{ac}}$ & D1 & E1 & 11 & 0 & 3.070 & $*$ \\
\hline $142 / 06309^{\mathrm{ac}}$ & D1 & E1 & 12 & 1 & 0.873 & $*$ \\
\hline $142 / 06310^{\mathrm{ac}}$ & D1 & E1 & 12 & 0 & 5.050 & $*$ \\
\hline $154 / 06618^{\mathrm{ac}}$ & D1 & E1 & 12 & 1 & 3.440 & $*$ \\
\hline $317 / 06065^{\mathrm{ac}}$ & D1 & E1 & 12 & 1 & 3.020 & $*$ \\
\hline $142 / 08369^{b}$ & S1 & D1 & 12 & 2 & 0.979 & $*$ \\
\hline $215 / 08753^{b}$ & $\mathbf{S 2}$ & D1 & 11 & 3 & -4.630 & $*$ \\
\hline $317 / 08046^{\mathrm{b}}$ & S4 & D1 & 12 & 1 & 1.890 & $*$ \\
\hline
\end{tabular}

${ }^{a}$ Kids to be removed from family and assigned to another sire after cross-referencing with on-farm data

${ }^{\mathrm{b}}$ Kids reassigned to family after cross-referencing with on-farm data

${ }^{c}$ Kids that were allocated to sires that were less than two years older than them by Cervus and were reallocated to the on-farm recorded sire

${ }^{\mathrm{d}}$ Confidence level: $*=$ strict confidence level (95\%) 
mean of 0.738. The most informative markers in terms of Polymorphic Information Content (PIC) were HSC (0.823), BM1258 (0.762) and BM1818 (0.752). The markers with the highest null allele frequency were INRA63 (+0.046) and BM7160 (+0.041), however these are still lower than 0.05 and therefore are still suitable for use in parentage verification (Marshall et al. 1998). Markers that performed with the highest probability of exclusion (PE), which is the ability of a marker to exclude a non-related sire as a potential sire (Marshall et al. 1998), were BM7160 (0.788), INRABERN 192 (0.758) and CSRD247 (0.721), The combined probability of exclusion (CPE) of the microsatellite marker panel for the current study was 0.996 .

The parentage analysis included all individuals in the study as a single population. The analysis was performed uniformly across all families, Family D is included here as an illustration (Table 2). The seven columns of Table 2 contain the following information: the on-farm recorded identification number for each offspring, the number of the sire that was assigned to each offspring by Cervus ${ }^{\mathrm{TM}}$ in this study, the number of the sire that was recorded for each offspring by the breeder, the number of loci that were compared between the allocated sire and the offspring by Cervus, the number of loci that did not correspond between the offspring and allocated sire, the LOD score for each parent-offspring allocation and the confidence with which the allocation is scored by Cervus ${ }^{\mathrm{TM}}$, respectively.

Cervus allocated additional offspring to Family D while reallocating six offspring from the original Family D to new sires. In instances where the breeder-recorded sire and the DNA-based allocated sire were related, the Cervus results were verified by cross-referencing with on-farm records. On consulting the kids' and sires' birth dates it was found that sire D1 was not old enough to have sired the kids allocated to him by Cervus. Angora goat bucks enter the breeding herd for the first time at 18 months of age, therefore, the sire would have to be at least two years of age at the kidding date of his offspring. Kids indicated by superscript "c" (Table 2) are offspring born in 2006, the same year of birth of the sire allocated by the DNA-based parentage verification, D1. In these cases, the kids were reassigned to the original sire that was recorded by the breeder, E1, who is the father of the DNA-based allocated sire, D1. These kids (indicated by superscript "a" in Table 2 were removed from Family D and allocated to Family E, of sire E1).

After taking the LOD score into account in cases where there were an equal number of mismatches between each sire and the offspring, birth dates of the kids were consulted. Kids born from September 
onwards were assigned to the DNA-verified sire and kids born before September were assigned to the breeder-recorded sire.

A total of 357 kids were successfully assigned to sires by Cervus, of which 40 kids did not have onfarm-recorded sires. $14.3 \%$ of the recorded pedigrees were inaccurate or incomplete. Most of the offspring which have been re-allocated to new sires were born during the middle to end of September, during the time when it is difficult to determine whether it was conceived by single-sire mating, or by group mating. Relatedness among the breeding sires resulted in a number of offspring being allocated to a relative of the true sire by Cervus ${ }^{\mathrm{TM}}$, however, by making use of statistical confidence values (LOD scores) of the parentage assignments and on-farm recorded data, the affected kids could be successfully allocated to the correct sire.

EBVs, accuracy of EBVs and rank for the body weight and fleece traits of sires estimated with the breeder's and DNA-verified pedigrees are summarized in Tables 3 and 4 respectively. From these tables it is evident that adding $0.8 \%$ known sires to the data set (40 kids out of 5077 kid records), and changing a further $0.22 \%$ sire pedigrees, had a marked influence on the breeding values, accuracies and ranking of the 21 sires included in the study.

The effect of the pedigree amendments on EBVs and sire rankings was most prominent in body weights. The EBV estimations and order of the sire ranks changed most drastically for birth weight (W0) and weaning weight (W4) as presented in Table 3.

Sire D1 was ranked the poorest-performing sire for birth weight based on the on-farm records and was re-ranked to the second highest position in the DNA-verified pedigree. Similarly, for weaning weight, the sire (sire A1) that was ranked as being the worst based on on-farm records was re-ranked as the best sire according to the DNA-verified pedigrees with a pronounced change in EBV as presented in Table 3. Sire S3 was ranked the best according to the pedigrees recorded by the breeder, but was ranked $18^{\text {th }}$ according to the DNA-verified pedigrees for weaning weight.

Although there was significant shuffling in the order of the sire ranks for birth and weaning weight the older body weights, including yearling weight and 16-month weight were less severely affected by the pedigree amendments (results not shown). The accuracies of the EBVs increased across all traits where more offspring were allocated to particular sires during the DNA-based assignment. 
Table 3 Estimated breeding values with accuracies (superscripts) and rankings of 21 sires for birth weight and weaning weight according to pedigrees recorded by the breeder and DNA-verified pedigrees

\begin{tabular}{|c|c|c|c|c|c|c|c|c|}
\hline Sire & W0 ${ }^{1}$ & $\mathrm{~W}^{2}$ & W0 ${ }^{1}$ Rank & $\mathrm{W}^{2}$ Rank & $\mathrm{W} 4^{1}$ & $\mathrm{~W} 4^{2}$ & W4 ${ }^{1}$ Rank & W4 ${ }^{2}$ Rank \\
\hline A1 & $-0.068^{94}$ & $0.051^{94}$ & 20 & 13 & $-0.80^{92}$ & $1.72^{91}$ & 21 & 1 \\
\hline B1 & $0.114^{94}$ & $0.011^{94}$ & 2 & 18 & $0.66^{93}$ & $0.33^{92}$ & 5 & 15 \\
\hline $\mathrm{C} 1$ & $0.088^{92}$ & $0.045^{92}$ & 4 & 14 & $1.63^{87}$ & $1.45^{86}$ & 2 & 3 \\
\hline D1 & $-0.116^{82}$ & $0.145^{81}$ & 21 & 2 & $0.29^{76}$ & $1.67^{74}$ & 9 & 2 \\
\hline E1 & $-0.012^{54}$ & $0.111^{94}$ & 15 & 5 & $-0.24^{47}$ & $0.87^{89}$ & 18 & 9 \\
\hline $\mathrm{F} 1$ & $0.037^{58}$ & $0.027^{88}$ & 7 & 16 & $0.13^{53}$ & $0.43^{82}$ & 13 & 14 \\
\hline G1 & $-0.029^{61}$ & $0.071^{92}$ & 18 & 7 & $-0.77^{57}$ & $1.35^{87}$ & 20 & 4 \\
\hline H1 & $0.035^{88}$ & $0.145^{88}$ & 9 & 3 & $-0.38^{83}$ & $0.86^{81}$ & 19 & 10 \\
\hline S1 & $0.030^{51}$ & $0.005^{78}$ & 10 & 19 & $0.79^{44}$ & $-1.19^{71}$ & 4 & 21 \\
\hline S3 & $-0.002^{79}$ & $0.070^{78}$ & 13 & 8 & $2.00^{78}$ & $0.15^{76}$ & 1 & 18 \\
\hline S4 & $-0.004^{51}$ & $0.032^{55}$ & 14 & 15 & $-0.22^{52}$ & $0.92^{56}$ & 17 & 6 \\
\hline S5 & $0.051^{61}$ & $-0.054^{65}$ & 6 & 21 & $0.52^{57}$ & $0.30^{58}$ & 8 & 16 \\
\hline S6 & $0.018^{58}$ & $-0.042^{62}$ & 12 & 20 & $0.62^{54}$ & $-0.10^{56}$ & 7 & 19 \\
\hline S7 & $0.022^{58}$ & $0.103^{59}$ & 11 & 6 & $-0.08^{54}$ & $1.09^{54}$ & 15 & 5 \\
\hline S8 & $0.101^{88}$ & $0.154^{88}$ & 3 & 1 & $0.94^{84}$ & $0.51^{83}$ & 3 & 13 \\
\hline S11 & $-0.040^{51}$ & $0.143^{81}$ & 19 & 4 & $0.16^{45}$ & $-0.71^{73}$ & 12 & 20 \\
\hline $\mathrm{S} 12$ & $0.037^{47}$ & $0.066^{59}$ & 8 & 11 & $0.63^{41}$ & $0.18^{50}$ & 6 & 17 \\
\hline S13 & $0.062^{61}$ & $0.070^{62}$ & 5 & 9 & $-0.16^{56}$ & $0.72^{57}$ & 16 & 12 \\
\hline S14 & $-0.014^{77}$ & $0.020^{76}$ & 16 & 17 & $0.18^{70}$ & $0.90^{69}$ & 10 & 7 \\
\hline S15 & $-0.016^{64}$ & $0.060^{68}$ & 17 & 12 & $0.17^{60}$ & $0.81^{61}$ & 11 & 11 \\
\hline S16 & $0.133^{61}$ & $0.069^{62}$ & 1 & 10 & $0.10^{56}$ & $0.88^{56}$ & 14 & 8 \\
\hline
\end{tabular}

'T: Value calculated using the on-farm-recorded pedigrees

${ }^{2}$ : Value calculated using the DNA-verified pedigrees

W0: Birth weight EBV

W4: Weaning weight EBV

W0 Rank: Sire rank for birth weight EBV

W4 Rank: Sire rank for weaning weight EBV

Accuracies of Estimated Breeding Values are printed as superscripts 
Table 4 Estimated breeding values, estimated breeding value accuracies (superscripts) and rankings of 21 sires for fleece weight and fibre diameter according to pedigrees recorded by the breeder and DNA-verified pedigrees

\begin{tabular}{|c|c|c|c|c|c|c|c|c|}
\hline Sire & $\mathrm{FW}^{1}$ & $\mathrm{FW}^{2}$ & $\mathrm{FW}^{1}$ Rank & $\mathrm{FW}^{2}$ Rank & $\mathrm{FD}^{1}$ & $\mathrm{FD}^{2}$ & $\mathrm{FD}^{1}$ Rank & $\mathrm{FD}^{2}$ Rank \\
\hline $\mathrm{A} 1$ & $0.029^{88}$ & $0.039^{89}$ & 10 & 10 & $2.51^{96}$ & $2.07^{94}$ & 19 & 20 \\
\hline B1 & $0.197^{90}$ & $0.174^{89}$ & 3 & 5 & $1.97^{97}$ & $1.51^{95}$ & 17 & 16 \\
\hline $\mathrm{C} 1$ & $-0.030^{82}$ & $-0.007^{83}$ & 18 & 18 & $0.53^{95}$ & $0.54^{90}$ & 9 & 10 \\
\hline D1 & $0.224^{79}$ & $0.217^{77}$ & 1 & 3 & $-1.27^{93}$ & $-1.12^{86}$ & 1 & 1 \\
\hline E1 & $0.172^{49}$ & $0.311^{86}$ & 4 & 1 & $0.28^{56}$ & $0.49^{93}$ & 7 & 9 \\
\hline F1 & $-0.036^{44}$ & $-0.077^{77}$ & 20 & 21 & $0.15^{57}$ & $1.03^{87}$ & 4 & 13 \\
\hline G1 & $0.107^{58}$ & $0.135^{89}$ & 8 & 8 & $1.88^{80}$ & $1.85^{94}$ & 16 & 18 \\
\hline H1 & $-0.020^{79}$ & $-0.001^{77}$ & 17 & 17 & $1.33^{94}$ & $1.46^{88}$ & 11 & 15 \\
\hline S1 & $0.075^{49}$ & $0.088^{58}$ & 9 & 9 & $3.17^{77}$ & $-0.09^{74}$ & 21 & 3 \\
\hline S3 & $0.006^{44}$ & $0.028^{43}$ & 14 & 13 & $-0.42^{63}$ & $-0.06^{56}$ & 2 & 4 \\
\hline S4 & $0.014^{49}$ & $0.009^{54}$ & 13 & 16 & $1.69^{55}$ & $0.37^{61}$ & 15 & 8 \\
\hline S5 & $0.199^{62}$ & $0.192^{58}$ & 2 & 4 & $2.44^{82}$ & $1.59^{73}$ & 18 & 17 \\
\hline S6 & $0.159^{54}$ & $0.136^{58}$ & 5 & 7 & $1.01^{78}$ & $0.55^{69}$ & 10 & 11 \\
\hline S7 & $-0.050^{49}$ & $-0.023^{49}$ & 21 & 19 & $1.46^{57}$ & $1.30^{56}$ & 13 & 14 \\
\hline S8 & $-0.033^{85}$ & $-0.026^{83}$ & 19 & 20 & $0.47^{96}$ & $0.23^{92}$ & 8 & 7 \\
\hline S11 & $0.003^{49}$ & $0.038^{74}$ & 15 & 11 & $0.26^{77}$ & $-0.43^{85}$ & 6 & 2 \\
\hline S12 & $0.028^{49}$ & $0.034^{54}$ & 11 & 12 & $0.25^{78}$ & $0.00^{68}$ & 5 & 5 \\
\hline S13 & $0.018^{49}$ & $0.021^{49}$ & 12 & 15 & $1.51^{54}$ & $1.02^{55}$ & 14 & 12 \\
\hline S14 & $-0.007^{54}$ & $0.027^{54}$ & 16 & 14 & $0.03^{78}$ & $0.10^{69}$ & 3 & 6 \\
\hline S15 & $0.113^{62}$ & $0.264^{63}$ & 7 & 2 & $1.46^{82}$ & $4.86^{74}$ & 12 & 21 \\
\hline S16 & $0.129^{58}$ & $0.144^{58}$ & 6 & 6 & $2.68^{80}$ & $1.93^{69}$ & 20 & 19 \\
\hline
\end{tabular}

': Value calculated using the breeder-recorded pedigrees

2: Value calculated using the DNA-verified pedigrees

FW: Fleece weight EBV

FW Rank: Sire rank for fleece weight EBV

FD: Fibre diameter

FD Rank: Sire rank for fibre diameter

Accuracies of Estimated Breeding Values are printed as superscripts

From the BLUP analysis for fleece traits, distinct differences can be seen in the EBV estimation and sire ranking and to a smaller extent, EBV accuracies as shown in Table 4. For fleece weight, the three highest ranking sires in the breeder-recorded pedigree (D1, S5 and B1) differed from those in the DNAverified pedigree (E1, S15 and D1); the three lowest ranking sires (F1, S7 and S8) remained the same, even though the order changed slightly. Six sires (S1, A1, C1, H1, G1 and S16) retained the same rank in the DNA-verified pedigree as in the breeder-recorded pedigree. EBV accuracies showed an overall improvement from the breeder-recorded pedigree to the DNA-verified pedigree. 
The results for fibre diameter differed from those of fleece weight. The highest ranking sire (D1) remained the same from the breeder-recorded pedigree to the DNA-verified pedigree. The other two highest ranking sires differed between pedigrees. Two of the three lowest sires corresponded between the two pedigrees, while the third of the lowest ranking sires ( $\mathrm{S} 1)$, that was ranked the lowest in the breeder-recorded pedigree was ranked the third highest in the DNA-verified pedigree. EBV accuracies for fibre diameter showed a variable trend, where accuracies for some sires increased, while it decreased for other sires when applying the DNA-verified pedigrees.

\section{Discussion}

The combined probability of exclusion (CPE) of the microsatellite panel for the current study was 0.996, which was lower than previous studies on goats reported by Jimenez-Gamero et al. (2006), Bolormaa et al. (2008) and Visser et al. (2011). This was expected as the animals selected for the study were chosen from one breeder and it is likely that replacement sires would be kept on the farm leading to higher levels of relatedness within the breeding herd.

The current study detected $3.1 \%$ errors (11 animals) in the on-farm pedigree records, which shows that human recording errors during AI and single-sire mating were minimal. Most mistakes were made with kids born during the overlapping time when it was difficult to determine whether the doe conceived through single-sire mating or group mating. Applying a window period where all rams are removed from the does for at least six to seven days could help in circumventing this problem. The total records amended, including 40 offspring that did not have on-farm paternity records, amounted to $14.3 \%$ (51 animals) of 357 offspring in the test population.

Relatedness and size of the candidate parent population has a direct effect on the probability of assigning unambiguous parentage (Sherman et al. 2004). This study confirmed that relatedness among the breeding parents in a herd can have a negative effect on parentage tests. Related individuals (especially sibling and parent-offspring pairs) tend to have alleles in common and this could result in offspring being allocated to another sire that is related to the true sire when using maximum likelihood allocation methods. In the present study, $12.3 \%$ of the offspring were erroneously allocated to a sire that was related to the true 
sire by DNA verification. Ambiguous paternities were confirmed with the use of on-farm records which confirmed parentage allocations. Overall, the results from the parentage analysis were acceptable and no cases were left unresolved. The study of Fisher et al. (2009) confirmed the increased statistical confidence achieved when combining on-farm records with genotypic data from DNA markers for parentage verification.

A large effect in sire ranking was observed in body weights after pedigrees were corrected. Sires B1, S3, S1, S8, S4 and G1 showed a ten-fold or more decrease in their EBVs and were initially ranked in the top five performing sires for different body weights in the on-farm pedigree, but shifted in rank to the five lowest performing sires in the DNA-verified pedigree. Similarly, sires D1, S11, A1, G1, H1 and F1 that were ranked in the lowest five performers in the on-farm pedigree were ranked among the top five producing sires $n$ the DNA-verified pedigree. This was most obvious in weaning weight, where sire A1, which was ranked lowest in the on-farm pedigree moved up to the top ranking position in the DNA-verified pedigree with an accuracy of above $90 \%$. This particular sire is one of the oldest of the sires included in the present study (born in 2001) and sired many offspring in the time period 2000 - 2009 (period in which all offspring in the dataset used for EBV estimation in the current study were born), which accounts for the high accuracy achieved. Similarly, for birth weight, sire D1 was ranked lowest in the on-farm pedigree and was ranked second in the DNA-verified pedigree with an accuracy of $82 \%$. This is a relatively young sire (born in 2006) but has shown above average performance in more than one trait.

The effect on sire ranking differed between the two fleece traits, which is what was expected as FW and FD are positively (but unfavourably) correlated (Visser et al. 2009). The impact of the DNA analysis was not as great on fleece traits as on growth traits in the current study. Most sires that were ranked in the top and bottom five performing sires remained there in the DNA-verified pedigree. A reason for this could be that the magnitude of selection pressure that had been placed on FW in the past resulted in most sires in the herd having positive EBVs for the trait. The EBVs for FW in the on-farm pedigree appear to be underestimated when comparing them to the DNA-verified pedigree.

The greatest impact of the change in EBV estimation after the pedigree amendment lies in the highest and lowest performing sires as these animals would be the most affected by selection decisions (Van 
Eenennaam et al. 2007). This was clearly demonstrated by the various body weights where the sires that were in reality the most superior sires were considered more inferior as a result of inadequate pedigree recording. Furthermore, the current limited participation of Angora goat breeders in performance testing schemes in South Africa presents a challenge to maximising genetic progress in these herds. The study of Sorensen (1987) demonstrated an increase in genetic progress of $29 \%$ when using EBVs compared to using mass selection. Selection indices have been developed for use in breeding programmes where breeders have the choice of using phenotypic data or EBVs in the index, depending on the availability of performance and pedigree records (Snyman, 2002; Olivier and Snyman, 2011).

The reordering of the pedigrees by microsatellite marker-based parentage verification had a profound effect on the estimation of EBVs and ranking of sires for the different traits considered in the study. The results of the study show potential for improvement of selection accuracy through the amendment of pedigree records. Gomez-Raya et al. (2008) performed a cost to benefit analysis for paternity testing in beef cattle in the United States and found that an additional return of between 70 and $140 \%$ may be made on the money invested in DNA paternity testing with microsatellite markers. Snyman and Olivier (1999) estimated that up to $2 \%$ genetic improvement may be made annually when selection is practiced using the selection indices designed specifically for use in South African Angora goat breeding schemes, with a potential added gain of up to $20 \%$ by basing these indices on EBVs.

Animal evaluations and EBV estimations rely on pedigree soundness for the results to be accurate and produce the expected results. This study has demonstrated how sires that were, in reality, the best producers appeared to be among the weaker performers of the selected sire group as a result of inaccurate pedigree records, and vice versa. These inaccuracies (left uncorrected) would most likely lead to flawed predictions of animal performance and impeded response to selection, which, in future years could lead to the decline in production and quality of the South African mohair clip.

\section{Conclusion}

The importance of pedigree soundness for genetic progress has been demonstrated by several studies in a number of livestock species, however unsound pedigrees remain a recurring limitation to genetic 
progress in many livestock breeding systems. Angora goat breeding in South Africa stands to benefit greatly by the advantage offered by DNA marker-based parentage verification in maintaining its competitive position in the global mohair market. The implementation of DNA-based parentage verification using microsatellite markers is an opportunity for Angora goat farmers to make more accurate selection decisions and greater genetic gains.

\section{Acknowledgements}

This research was supported by the International Foundation for Science, Stockholm, Sweden through a research grant (B/4998-1). This work is based on the research supported in part by a number of grants from the National Research Foundation of South Africa (UID: 78566 (NRF RISP grant for the ABI3500)). The Grant holders acknowledge that opinions, findings and conclusions or recommendations expressed in any publication generated by the NRF supported research are that of the author(s), and that the NRF accepts no liability whatsoever in this regard.

\section{References}

Avdi, M., Banos, G., 2008. Genetic diversity and inbreeding in the Greek Skyros horse. Livest. Sci.114, 362365.

Banos, G., Wiggans, G.R., Powell, R.L., 2001. Impact of paternity errors in cow identification on genetic evaluations and international comparisons. J. Dairy Sci. 84, 2523-2529.

Belonsky, G.M., Kennedy, B.W., 1988. Selection on individual phenotype and best linear unbiased predictor of breeding value in a closed swine herd. J. Anim. Sci. 66, 1124-1131.

Bolormaa, S., Ruvinsky, A., Walkden-Brown, S., Van der Werf, J., 2008. DNA-based parentage verification in two Australian goat herds. Small Rumin. Res. 80, 95-100.

DAFF (Department of Agriculture, Forestry and Fisheries), 2013. Trends in the Agricultural Sector. P68 69. 
Fisher, P.J., Malthus, B., Walker, M.C., Corbett, B., Spelman, R.J., 2009. The number of single nucleotide polymorphisms and on-farm data required for whole-herd parentage testing in dairy cattle herds. J. Dairy Sci. 92, 369-274.

Friedrich, H., 2009. Evaluation of microsatellite markers for parentage verification in South African Angora goats, MScAgric dissertation, University of Pretoria, Pretoria, viewed 2011/06/28 http://upetd.up.ac.za/thesis/available/etd-09012010-170032/ >

Gilmour, A. R., Cullis, B. R., Welham, S.I., Thompson, R., 2002. ASReml Reference Manual (2nd ed.) NSW Agriculture Biometrical Bulletin 3, NSW Agriculture, Australia.

Gomez-Raya, K., Priest, W.M., Rauw, M., Okomo-Adhiambo, D., Thain, B., Bruce, A., Rink, R., Torell,L., Grellman, R., Narayanan, R., Beattie, C.W., 2008. The value of DNA paternity identification in beef cattle: Examples from Nevada's free range ranches. J. Anim. Sci. 86, 17-24.

Goosen, P., Swart, A.C., Storbeck, K-H., Swart, P., 2010. Hypocortisolism in the South African Angora goat: The role of 3ßHSD. Mol. Cell. Endocrinol. 315, 182-187.

Jimenez-Gamero, I., Dorado, G., Mu_oz-Serrano, A., Analla, M., Alonso-Moraga, A., 2006. DNA microsatellites to ascertain pedigree-recorded information in a selecting nucleus of MurcianoGranadina dairy goats. Small Rumin. Res., 65, 266-273.

Long, T.E., Johnson, R.K., Keele, J.W., 1990. Effects of errors in pedigree on three methods of estimating breeding value for litter size, backfat and average daily gain in swine. J. Anim. Sci. 68, 4069-4078.

Mohair South Africa, 2012. Mohair Review. http://www.mohair.co.za/wp-content/uploads/2013/11/ Mohair Review_2012.pdf [Accessed 23/03/2013]

Marshall, T.C., Slate, J., Kruuk, L.E.B., Pemberton, J.M., 1998. Statistical confidence for likelihood based paternity inference in natural populations. Mol. Ecol., 7(5), 639-655.

Morrell, C.H., 1998. Likelihood ratio testing of variance components in the linear mixed effects model using restricted maximum likelihood. Biometrics 54, 1560-1568.

Olivier, W.J., Snyman, M.A., 2011. Interpretation and application of performance testing data. Grootfontein Agric. 11(1). 
Park, S.J., 2001. Microsatellite Toolkit for Excel. Smurfit Institute of Genetics, Trinity College, University of Dublin, Ireland.

Pollak, E.J., 2005. Application and impact of new genetic technologies on beef cattle breeding: a "realworld" perspective. Aus. J. Experimental Agric. 45, 739-748.

Putnova, L., Knoll, A., Dvorak, V., Dvorak, J., 2003. A novel porcine microsatellite panel for the identification of individuals and parentage control on the Czech Republic. Czech J. Anim. Sci. 48(8), 307-314.

Queller, D.C., Strassmann, J.E., Hughes, C.R., 1993. Microsatellites and Kinship. Elsevier Science Publishers Ltd (UK) 0169-5347/93. 285-288.

Rendo, F., Iriondo, M., Manzano, C., Estonba, A., 2011. Microsatellite based ovine parentage testing to identify the source responsible for the killing of an endangered species. Forensic Sci. Int. 5, 333-335.

SAS, 2009. SAS OnlineDoc® 9.2. SAS Institute Inc., Cary, N.C., USA.

Sherman, G. B., Kachman, S. D., Hungerford, L. L., Rupp, G. P., Fox, C. P., Brown, M. D., Feuz, B.M., Holm, T. R., 2004. Impact of candidate sire number and sire relatedness on DNA polymorphism-based measures of exclusion probability and probability of unambiguous parentage. Anim. Genet, 35(3), 220-226.

Slate, J., Marshall, T., Pemberton, J., 2000. A retrospective assessment of the accuracy of the paternity inference program CERVUS. Mol. Ecol. 9(6), 801-808.

Snyman, M.A., 2002. Evaluation of a genetically fine mohair producing herd. Small Rumin. Res. 43, 105113.

Snyman, M.A., 2007. Body weight and growth rate of South African Angora goat kids under different preand post-weaning management systems. S. Afr. J. Anim. Sci. 37(2), 132-141.

Snyman, M.A., 2011a. Influence of body weight, age and management system on reproduction of South African Angora goat does. S. Afr. J. Anim. Sci. 40(1), 41-53.

Snyman, M.A., 2011b. Factors affecting pre-weaning kid mortality in South African Angora goats. S. Afr. J. Anim. Sci. 40(1), 54-64. 
Snyman, M.A., 2012. Genetic analysis of body weight in South African Angora kids and young goats. S. Afr. J. Anim. Sci. 42(2), 146-155.

Snyman, M.A., Olivier, J.J., 1999. Performance testing - The road to future Angora goat breeding. Angorabok- en Sybokhaarblad

Snyman, M.A., Olivier, J.J., Wentzel, D., 1996. Breeding plans for South African Angora goats. Angora Goat Mohair Journal 38, 23-31.

Sørensen, D.A., 1987. Effect of alternative methods of breeding value estimation on response to selection in simulated pig populations. Proc. 38th Annual. Meet. Europ. Assoc. Anim. Prod. 11, 1164.

Van Eenennaam, A.L., Weaber, R.L., Drake, D.J., Penedo, M.C., Quaas, R.L., Garrick, D.J., Pollak, E.J., 2007. DNA-based paternity analysis and genetic evaluation in a large commercial cattle ranch setting. J. Anim. Sci. 85, 3159-3169.

Visscher, P.M., Woolliams, J.S., Smith, D., Williams, J.L., 2002. Estimation of pedigree errors in the UK dairy population using microsatellite markers and the impact on selection. J. Dairy Sci. 85, 2368-2375.

Visser, C., Snyman, M.A., van Marle-Köster, E., Bovenhuis, H., 2009. Genetic parameters for physical and quality traits of mohair in South African Angora goats. Small Rumin. Res. 87(1-3), 27-32.

Visser, C., van Marle-Köster, E., Friedrich, H., 2011. Parentage verification of South African Angora goats using microsatellite markers. S. Afr. J. Anim. Sci. 41(3), 250-255.

Webster, M.S., Reichart, L., 2005. Use of microsatellites for parentage and kinship analyses in animals. Methods Enzymol. 395(14), 222-238. 